\title{
RESEARCH ON THE SOILS OF KARST AREAS IN HUNGARY (EXAMPLE FROM BÜKK MOUNTAIN)
}

\section{RAZISKAVE PRSTI NA MADŽARSKEM KRASU (PRIMER IZ POGORJA BÜKK)}

ZSENI ANIKÓ1

${ }^{1}$ Department of Physical Geography, University of Szeged, HUNGARY

Prejeto / received: 15. 7. 1999 


\section{Zseni Anikó: Raziskave prsti na madžarskem krasu (primer iz pogorja Bükk)}

Avtorica je preučevala značilnosti hranilnega sistema prsti na madžarskem krasu, to je na $8 \mathrm{~km}^{2}$ površja planote Bükk. 63 vzorcem prsti je bil izmerjen $\mathrm{pH}$ ter vsebnost karbonatov, celokupna količina dušika, vsebnost rastlinam dostopnega kalcija, kalija, magnezija in fosforja. Tako je lahko primerjala hranilne sisteme prsti iz različnih ekoloških okolij. Glede hranilne vrednosti prsti so razlike med bukovim in borovim gozdom ter odprtim poljem. Poznavanje $\mathrm{pH}$ ter vsebnosti N, P, K, Ca, Mg v prsteh je lahko pomembno za varstvo okolja, za vzdrževanje gozdarstva in urejanja travnikov.

Ključne besede: pedogeografija, kras, hranilna vrednost prsti, Bükk, Madžarska.

\section{Abstract}

UDC: 631.4:551.44(439)

\section{Zseni Anikó: Research on the soils of karst areas in Hungary (example from Bükk Mountain)}

The author studied the characteristics of the soil nutrient system in a Hungarian karst area, that is on $8 \mathrm{~km}^{2}$ area of the Bükk plateau. The $\mathrm{pH}$, total carbonate content, total soil-nitrogen content, plant available calcium, potassium, magnesium, and phosphorus contents of 63 soil samples were measured. She was able to compare the nutrient system of the soils which occurred in different ecological conditions. There are differences between the nutrient status of the soils of the beech and pine forest and the open fields. The knowledge of the $\mathrm{pH}$ plus the $\mathrm{N}, \mathrm{P}, \mathrm{K}, \mathrm{Ca}, \mathrm{Mg}$ content of the soils can be important regarding the protection of the environment, the maintenance of the forest and the management of the meadows.

Key words: pedogeography, karst, soil nutrient status, Bükk, Hungary. 


\section{INTRODUCTION}

I studied the characteristics of the soil nutrient system in karst areas. In the last ten years the investigation of soils that occur on Hungarian karst came into prominence. The soil has an important role in the ecological system because it can buffer the harmful environmental effects that take effect quickly. Determination of soil nutrients is not common in karst areas, so we have few results on this subject. There is only one soil profile in the Bükk plateau where among others the nutrients were determined. But there are great differences in the nutrient supply of the soil on small areas especially if we investigate this in different ecological conditions.

\section{DISCUSSION}

I examined an $8 \mathrm{~km}^{2}$ part of the Bükk plateau (Bükk National Park, Hungary). From every km² we collected 2 soil samples (from depths of 5-10, 10-20, 20-30,30-40 cm). These came from different ecological conditions: beech forests, pine forests, beech with pine forests, woodland nursery and open field.

Of the nutrients of the soil I measured the quantity of total soil nitrogen plus the quantity of plant-available phosphorus, potassium, calcium, magnesium. Although it is not actually a type of nutrient I also measured the collective quantity of exchangeable and solution sodium. This enabled me to calculate the S-value (exchangeable basis) of the soils.

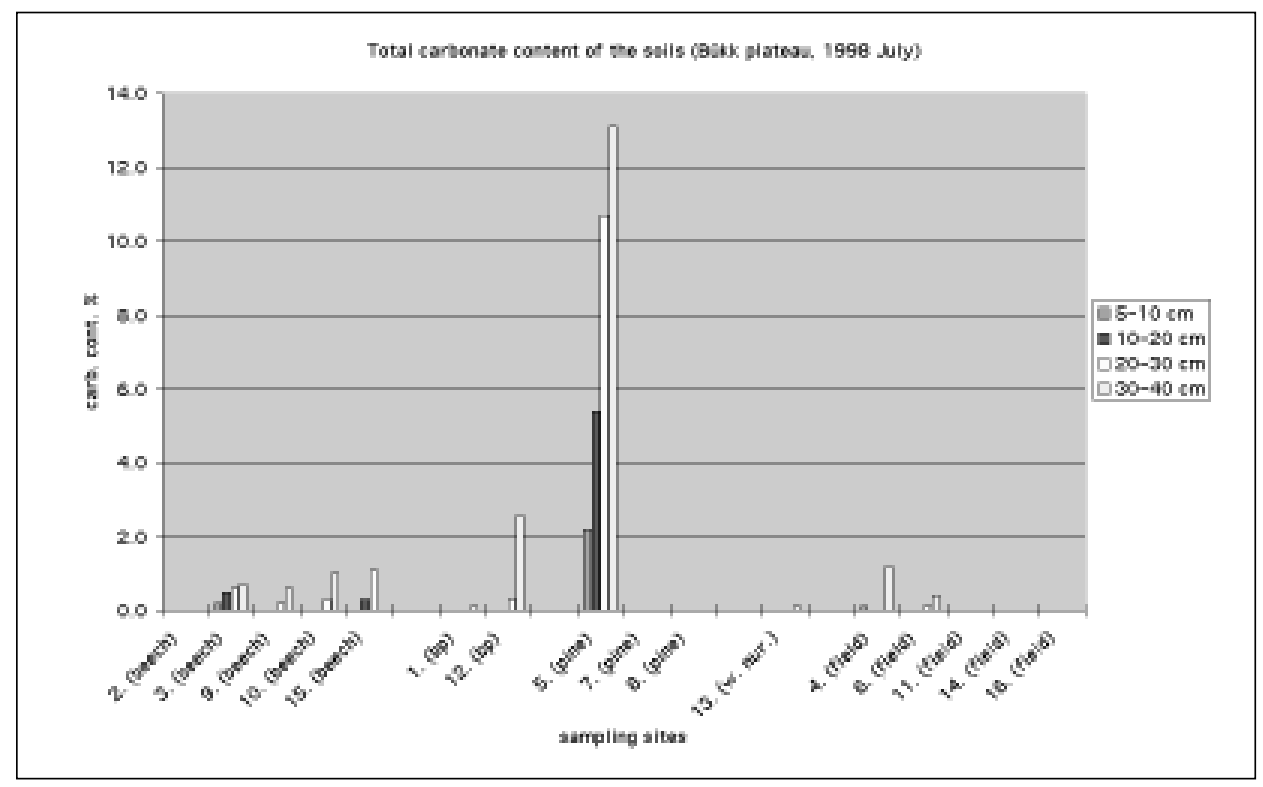

Fig. 1: Total carbonate content of the soils (Bükk plateau, 1998 July). 
The plant-available $\mathrm{Mg}$ and $\mathrm{Ca}$ contents were measured on an Atomic Absorption Spectrophotometer, and the $\mathrm{K}$ and $\mathrm{Na}$ with a flame photometer (extracted by $1 \mathrm{~mol} / \mathrm{dm}^{3}$ $\mathrm{CH}_{3} \mathrm{COONH}_{4}$ ). I used the modification of the technique devised by Kjeldahl to determine the total $\mathrm{N}$ and the Olsen's method to measure the plant available $\mathrm{P}$.

The investigation of the soil cannot be done without a knowledge of the $\mathrm{pH}$ and the carbonate content of the soil. Therefore during the investigation I determined the $\mathrm{pH}\left(\mathrm{H}_{2} \mathrm{O}\right)$ and $\mathrm{pH}(\mathrm{KCL})$ plus the carbonate content of soils. The soil moisture - which is important for the plants' take-up of nutrients - was also part of the investigation.

The determination of $\mathrm{pH}$ and carbonate content of soils is not only important because of the nutrients. In the case of karst areas it is important to know these connections because the characteristic of the bedrock point towards the fact that the soil has a high carbonate content and from this has neutral $\mathrm{pH}$. After the measurement I made I found that the soils of Bükk plateau has a low carbonate content which has a big influence of the presence of the nutrients (Fig. 1). In connection with this the $\mathrm{pH}$ of the soils is also lower than expected. In the case of $\Delta \mathrm{pH}\left(=\mathrm{pH}\left(\mathrm{H}_{2} \mathrm{O}\right)-\mathrm{pH}(\mathrm{KCL})\right)$ the often high (around 1) values show that in these soils the acidification is important (Fig. 2, 3, 4, 5).

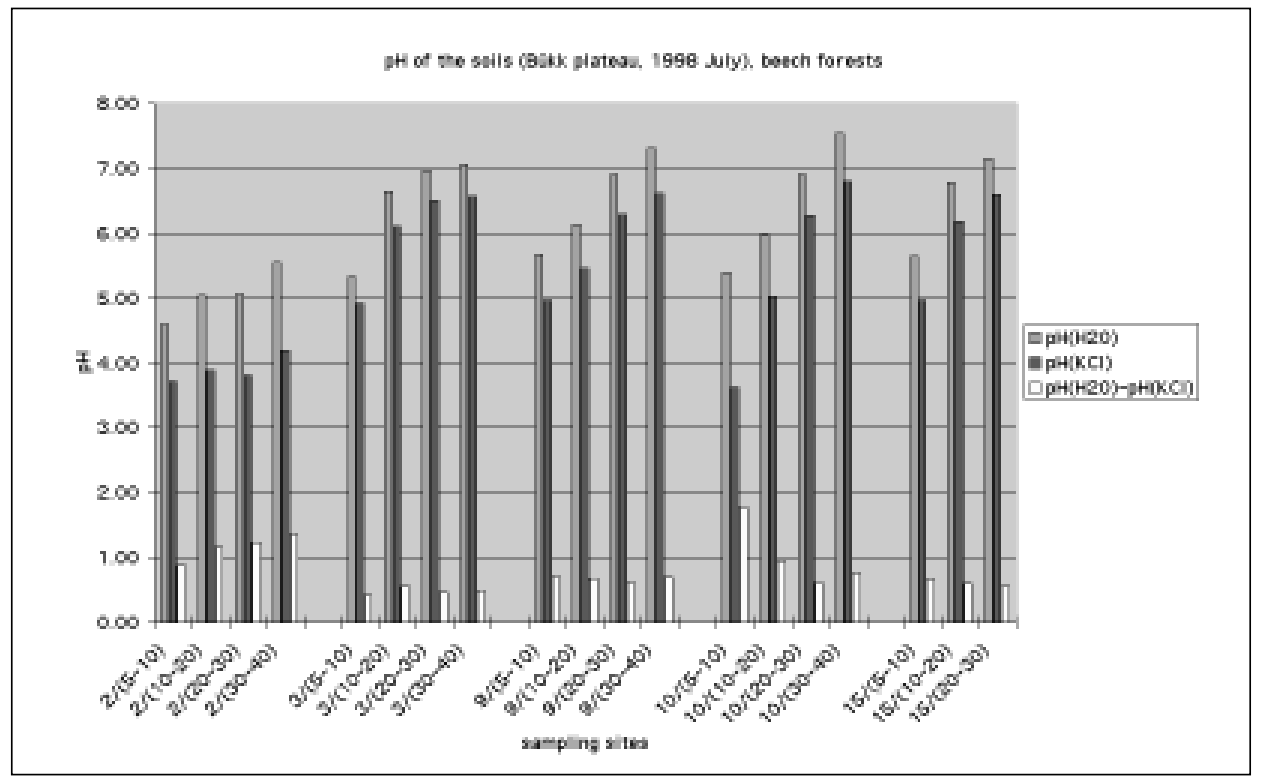

Fig. 2: pH of the soils (Bükk plateau, 1998 July), beech forests. 
Zseni Anikó: Research on the soils of karst areas in Hungary (example from Bükk Mountain)

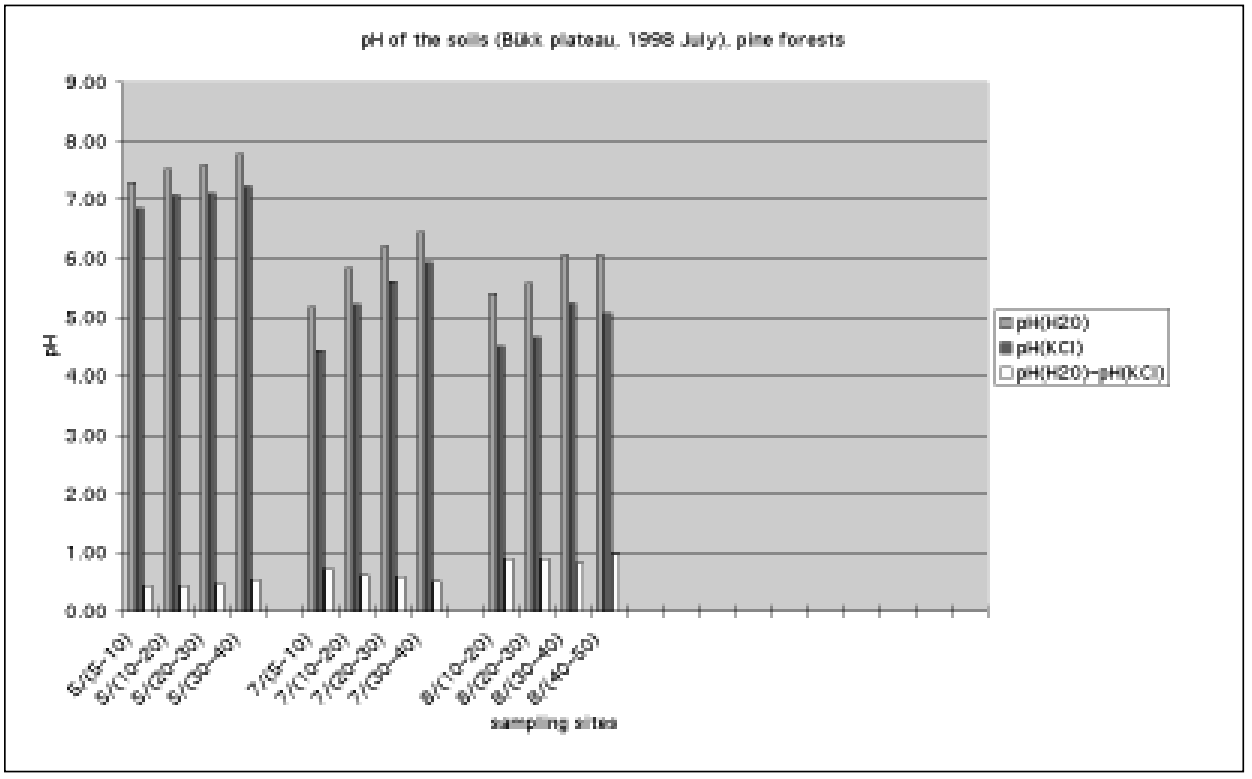

Fig. 3: pH of the soils (Bükk plateau, 1998 July), pine forests.

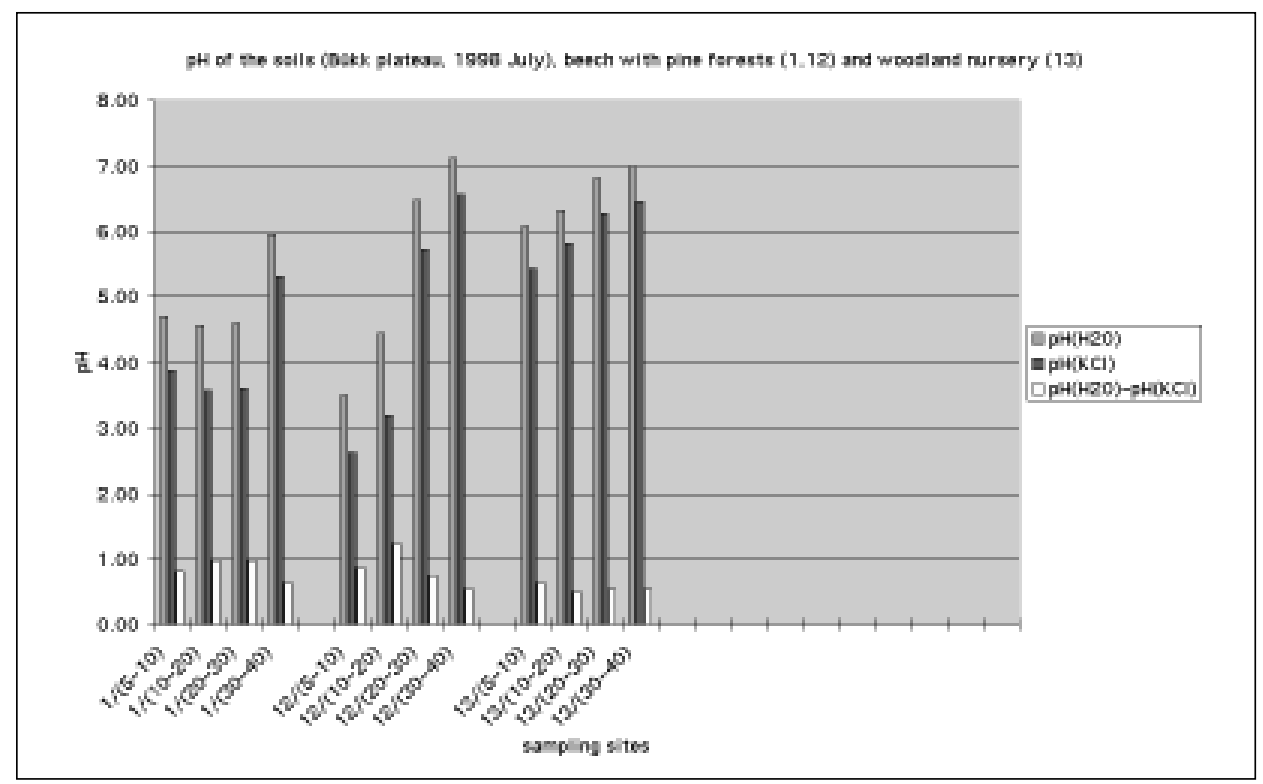

Fig. 4: pH of the soils (Bükk plateau, 1998 July), beech with pine forests (1,12) and woodland nursery (13). 


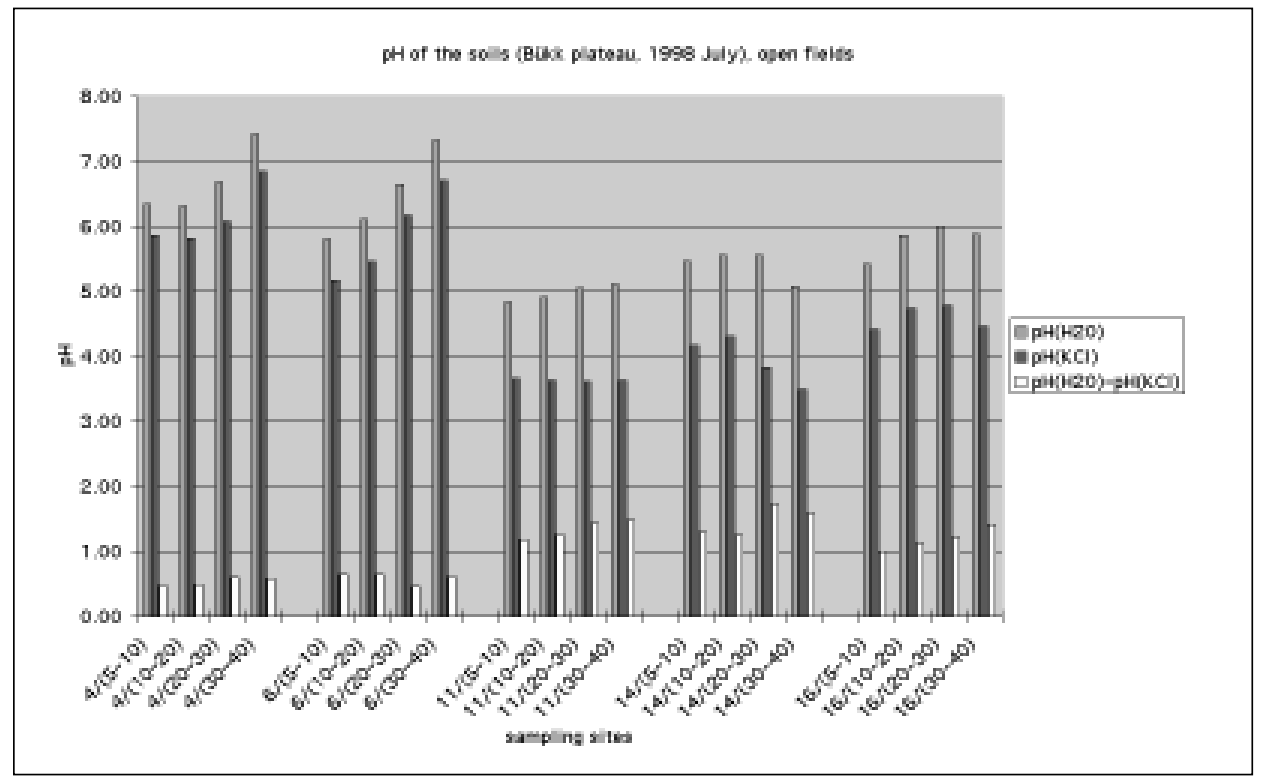

Fig. 5: pH of the soils (Bükk plateau, 1998 July), open fields.

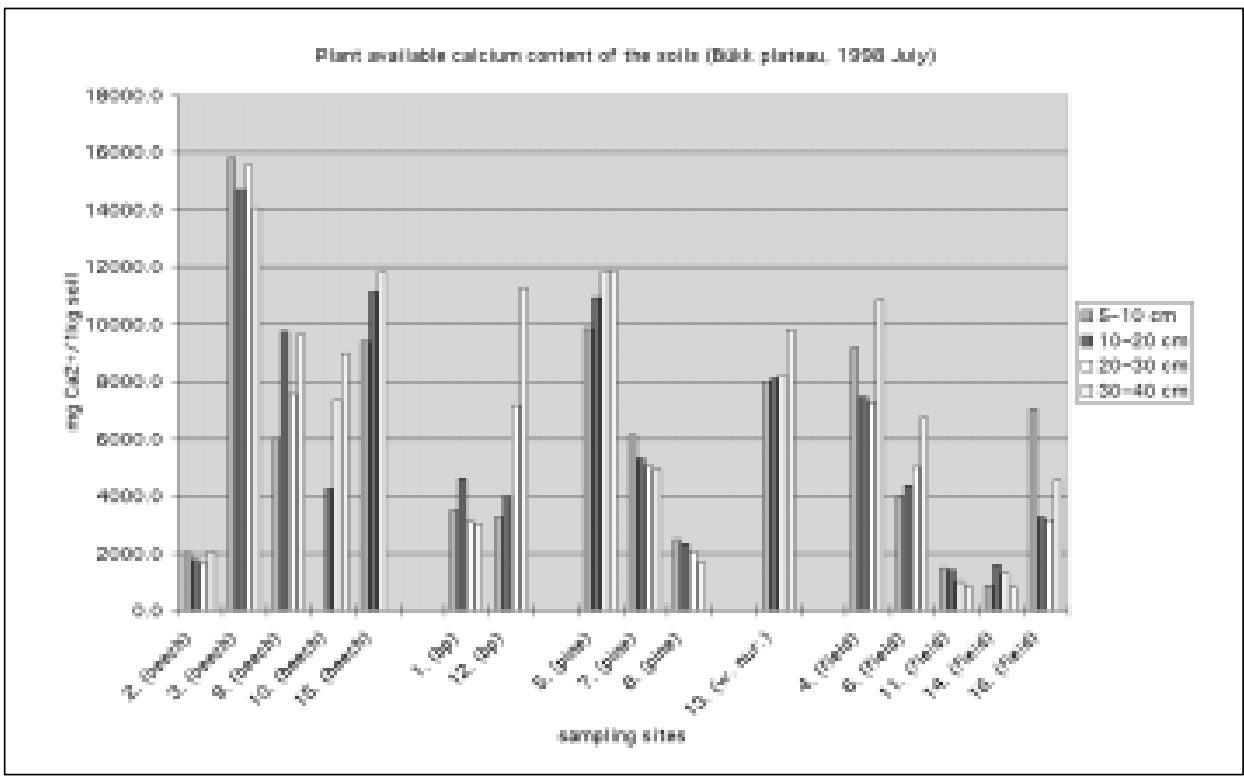

Fig. 6: Plant-available calcium content of the soils (Bükk plateau, 1998 July). 
On the basis of the results we may come to some conclusions:

1. The nutrient indices of the soils of the beech forest and beech with pine forest are the most advantageous in respect of the plant-available calcium, magnesium, potassium and total nitrogen.

2. The soils of the open fields have the lowest nutrient status except the plant-available phosphorus, with which they are the best supplied.

3. The $\mathrm{pH}$ is related to the calcium content of the soil (Fig. 6). The soils with lower $\mathrm{pH}$ have a lower plant available calcium content. The soils which are mixed with fragments of limestone (Sample sites 1., 2., 3., 4., 5., 6., 9., 10., 12., 13., 15.) have a higher plant-available calcium content than those which are not (Sample sites 7., 8., 11., 14., 16.). In the soils in which the $\Delta \mathrm{pH}$ is high the plant-available calcium content is always low. In the soils which are mixed with fragments of limestone the $\mathrm{pH}$ and plant-available calcium content increase downwards in the soil profile. The plant-available calcium content decreases downwards in the soils which have not been mixed with limestone.

4. The plant-available calcium is related to the plant-available potassium and magnesium; the higher the calcium content the higher the potassium and magnesium content and vice versa.

5. The difference of the potassium content of soil between the different types of plants is lower than that in the case of the other nutrients.

6. The soils are weakly supplied with magnesium. This is interesting because most of the examined soils in Hungary are well supplied. I have some soil samples in which the plant-available magnesium content is lower than the lowest limit of the method of measuring.

7. More than half of the examined soils are well supplied with phosphorus. On average the soils of the open fields have the highest plant-available phosphorus content.

8. The soils are weakly and moderate supplied with nitrogen.

There are a lot of interesting links between the nutrients and the ecological conditions. Let me point out one of them.

The open fields can be divided into two groups because of the $\mathrm{pH}$, total carbonate content and plant-available calcium content of these soils. The soils of the 4. and 6. fields have higher $\mathrm{pH}$ and plant-available calcium content than the soils of the 11., 14. and 16. fields. In those two soils the pH increases downwards in the soil profile while in the latter three soils does not. These three soils have very high $\mathrm{DpH}$ values (1-1,7) which show that in these soils the acidification is important. There is no carbonate content in the soils of the 11., 14. and 16. fields. In the other two soils the carbonate appears in the depth of $15-20 \mathrm{~cm}$. The environmental conditions prove the dividing of the five fields into two parts. In the case of the 4. and 6. fields the limestone fragments appear in the depth of $15-20 \mathrm{~cm}$ in the soil profile. But in the 11., 14., 16. soils we were not able to reach the parent material to the examined depth, so there were no fragments in these soils. 


\section{BIBLIOGRAPHY}

Bárány I. (1980): Some data about the physical and chemical properties of the soil of karst dolines. Acta Geographica pp.37-49

Bárány-Kevei I. (1992): Karst soil as indicators of karst developement in Hungarian karst. Zeitdchrift für Geomorphologie N.F., Supplement, 85, pp.101-110

Bárány I. - Mezõsi G. (1978): Adatok a karsztos dolinák talajökológiai viszonyaihoz. Földrajzi Értesítõ 1. füzet pp.65-73

\section{RAZISKAVE PRSTI NA MADŽARSKEM KRASU (PRIMER IZ POGORJA BÜKK)}

\section{Povzetek}

Preučevala sem hranilne značilnosti prsti na kraških področjih Madžarske, v tem prispevku predstavljam rezultate raziskav na $8 \mathrm{~km}^{2}$ ozemlja na planoti Bükk (Nacionalni park Bükk). Z vsakega kvadratnega kilometra ozemlja sem vzela po dva vzorca prsti (iz globine 5-10, 10-20, 20-30, 30-40 $\mathrm{cm})$. Vzorci so bili vzeti iz različnih ekoloških okolij: iz bukovega, borovega, bukovo-borovega gozda, iz mladega gozdnega nasada in z odprtega sveta.

V zadnjem desetletju je na Madžarskem postalo raziskovanje prsti zelo pomembno. Prst namreč igra v ekološkem sistemu zelo pomembno vlogo, ker lahko zadrži in ublaži tiste škodljive vplive na okolje, ki bi sicer lahko imeli zelo hitre posledice.

Izmed hranilnih snovi v prsti sem za meritve izbrala celotno količino dušika ter za rastline dostopnega fosforja, kalija, kalcija in magnezija. Čeprav ni hranilna snov, sem merila tudi skupno količino natrija v raztopini in natrija, ki je na razpolago za izmenjavo.To mi je namreč omogočilo računanje vrednosti $S$ (osnove za izmenjavo) prsti.

Prsti ni mogoče preučevati, ne da bi poznali vrednosti $\mathrm{pH}$ in količino karbonatov v prsti. Zato sem vzporedno z ostalimi raziskavami določala tudi $\mathrm{pH}\left(\mathrm{H}_{2} \mathrm{O}\right)$ in $\mathrm{pH}(\mathrm{KCl})$ ter vsebnost karbonatov. Tudi ugotavljanje vlažnosti prsti, ki je pomembna zato, da lahko rastline vsrkavajo hranilne snovi, je bilo del mojih raziskav.

Vendar določanje $\mathrm{pH}$ in karbonatov v prsti ni pomembno le z vidika hranilnih snovi. Na krasu je poznavanje teh povezav pomembno tudi zato, ker značilnosti kamninske osnove omogočajo visoke vsebnosti karbonatov in torej nevtralno $\mathrm{pH}$ reakcijo. Moje raziskave pa so pokazale, da imajo prsti na planoti Bükk nizko vsebnost karbonatov, kar močno vpliva na prisotnost hranil. Skladno s tem je tudi $\mathrm{pH}$ nižji od pričakovanega. $\mathrm{V}$ tem primeru je $\Delta \mathrm{pH}\left(=\mathrm{pH}\left(\mathrm{H}_{2} \mathrm{O}\right)-\mathrm{pH}(\mathrm{KCL})\right)$ često visoka (okoli 1), kar kaže na močno zakislevanje prsti.

Poznavanje $\mathrm{pH}$ in vsebnosti N, P, K, Ca in Mg v prsti je lahko zelo pomembno za varovanje okolja, ukrepe v gozdarstvu in za vzdrževanje travnih površin na planoti Bükk. 